\title{
WHY DO CEOS RECIPROCALLY SIT ON EACH OTHER'S BOARDS?
}

\author{
Eliezer M. Fich ${ }^{\natural}$ \\ Kenan- Flagler Business School \\ University of North Carolina \\ Chapel Hill, NC 27599-3490 \\ Tel: $919-962-6121$ \\ Fax: 919-962-2068 \\ efich@unc.edu
}

\author{
Lawrence J. White \\ Stern School of Business \\ New York University \\ New York, NY 10012-1126 \\ Tel: 212-998-0880 \\ Fax: 212-995-4218 \\ lwhite@stern.nyu.edu
}

Draft: January 16,2001

\begin{abstract}
The reciprocal interlocking of chief executive officers (CEOs) is a non-trivial phenomenon of the composition of boards of directors and of corporate governance: among large companies in 1991, about one company in seven is part of a relationship whereby the CEO of one company sits on a second company's board and the second company's CEO sits on the first company's board. We are aware of no previous efforts to explain these reciprocal relationships. We hypothesize that reciprocal CEO interlocks are (a) more likely when a board has more outside directorships, (b) less likely when a CEO has more of his total annual compensation paid in the form of stock options, (c) less likely when a company's board is more active and holds more meetings, (d) less likely when a CEO has a larger ownership share of his company, and (e) more likely when there are more CEOs from other companies as outside directors on a CEO's board. Using a sizable sample of large companies in 1991, we employ simple probit and step probit models to test these hypotheses, with the use of control variables that encompass other company, board, and CEO characteristics. These multivariate analyses support our first three conjectures but do not support the remaining two.

Since there is considerable academic and policy debate concerning board composition and the effectiveness of interlocking directorships in general, investigations focusing on reciprocal CEO interlocks, which link the highest ranked executives of two different firms, represent a significant contribution to the knowledge base in this field.
\end{abstract}

Keywords: Interlocking directorates; CEOs; Board of directors; Corporate governance; Stock options

\footnotetext{
* We would like to thank Jay Hartzell, Rob Hansen and David Yermack and the participants at a seminar at the University of North Carolina for their valuable comments and suggestions. We would also like to thank our discussant Tatiana Nenova at the American Finance Association 2001 meetings for her comments on the paper. Fich gratefully acknowledges financial support in the research and writing of this manuscript from a Willensky fellowship from the Stern School.
} 
JEL classification: G34; J33; K22 


\title{
WHY DO CEOS RECIPROCALLY SIT ON EACH OTHER'S BOARDS?
}

\author{
Eliezer M. Fich \\ Lawrence J. White
}

\section{Introduction}

The practice of interlocking directorates ${ }^{\mathbb{1}}$ has been a subject of debate among corporate governance activists and academics for many decades. Although Section 8 of the Clayton Act of 1914 prohibited interlocking directorates between competing firms, it did not prohibit board interlocks in general. The proxy disclosure rules promulgated by the Securities and Exchange Commission (SEC) in 1992 require firms to disclose director interlocks where matters of executive compensation are concerned. The National Association of Corporate Directors Blue Ribbon Commission guidelines (NACD, 1996) advocate the avoidance of interlocking directorates. In practice, interlocking directorates occur regularly across industries and have often been favorably praised, since they mobilize a scarce resource: the expertise of senior managers and directors of large corporations.

Recent studies in financial economics have devoted attention to the possible implications of interlocking directorates. ${ }^{2}$ However, none have considered the factors that determine why firms might reciprocally share the services of their most senior executives -specifically, their chief executive officers (CEOs) -- through mutual board membership. We note that these types of reciprocal interlocks are a non-trivial phenomenon: among large companies in 1991, one firm in seven is involved in this type of reciprocal interlock. Since

\footnotetext{
${ }^{1}$ An interlocking directorate is defined as the phenomenon whereby a person is on the board of directors of two or more corporations, thereby providing a link or interlock between them.

${ }^{2}$ See, for example, Hallock (1997) and Core, Holthausen, and Larcker (1999).
} 
there is considerable academic and policy interest in board composition and interlocking directorates generally, the development of new information about reciprocal CEO interlocks, which involve the corporate executives with the greatest authority and marginal productivity (Smith and Watts, 1992) as well as the potential for substantially influencing board activities, represents a significant expansion of the knowledge base in this field.

Our objective is to examine the factors that explain this reciprocal interlocking of CEOs. A reciprocal CEO interlock occurs when the CEO of firm $i$ serves as a director of firm $j$, and the CEO of firm $j$ serves as a director of firm $i$. Our empirical results indicate that the reciprocal interlocking of CEOs is more likely to occur in firms where directors have larger numbers of outside directorships. Our findings also indicate that the probability of a reciprocal CEO interlock decreases for CEOs who derive high fractions of their total compensation from stock options. In addition, we report a negative association between the incidence of reciprocal CEO interlocks and the number of meetings that the board holds during the fiscal year. Two other hypotheses that we develop -- that reciprocal CEO interlocks should be less likely where a CEO has larger ownership position in his company and should be more likely where the number of CEOs from other companies sit on the CEO's board of directors -- are not supported in our multivariate analysis (although we do find support for them in our univariate analysis).

These results contribute to the corporate governance literature by identifying some of the determinants of a significant category of board interlocks -- specifically, those involving reciprocal CEO interlocks -- and they advance the general understanding of the composition of corporate boards and the outside-the-firm decisions of CEOs. In addition, 
our results shed some direct and indirect light on the implications of reciprocal CEO interlocks for shareholder wealth.

Our paper proceeds as follows: The next section reviews the prior academic literature studying interlocking directorates. Our theories and hypotheses are contained in Section 3. Section 4 describes the sample selection and the data used in this study. Empirical analyses and results are the subject of Section 5. In Section 6 we provide a summary and conclusions of this study.

\section{Literature Review}

A simple board interlock occurs when a person serves on the board of more than one company. Mutually interlocking relationships are defined to occur when at least two directors together serve on the boards of two different corporations. ${ }^{\text {目 }}$ When a sense of direction to this mutuality can be identified -- as when, for example, the CEO of one company is serving on the board of a second company, while the CEO of that second company is also serving on the board of the first -- we define this as reciprocal interlocking.

One of the first academic studies in the United States to consider simple board interlocks is Dooley (1969). Dooley finds that less solvent firms were likely to be interlocked with banks. Later studies also report that firms with high debt-to-equity ratios (Pfeffer, 1972) or organizations with an increased demand for capital (Mizruchi and Stearns, 1988) have a higher tendency to interlock their boards. Two possible interpretations can be drawn from these studies. On the one hand, it is possible that financially distressed firms seek to add bank officers to their boards in order to receive favorable consideration from the

\footnotetext{
${ }^{3}$ This definition is used in Fich (2000a).
} 
lending institution. On the other hand, banks could demand to have one or more of its officers as a board director in order to monitor the firm's investment prospects more closely. However, Kroszner and Strahan (1999) find that banks tend to avoid having an officer sit on the board of a company to which they have lent and that may become financially troubled, because of concerns about subsequent claims of conflict of interest. Also, Kracaw and Zenner (1998) examine the stock price reactions to bank loan announcements when the bank and the borrower have interlocking directorates. They find significant negative returns to bank loan announcement when a bank officer serves on the borrower's board. They note that the negative reactions are less prevalent among larger firms.

Behaviorists argue that companies use board-interlocks as a mechanism to improve contracting relationships (Schoorman, Bazerman, and Atkin, 1981). Some papers in this literature focus on the reconstitution of broken or disrupted interlock ties between firms (e.g., Palmer, 1983) or in the assessment of the importance of interlocks in reducing the information uncertainties created by resource dependencies between firms (Pettigrew, 1992).

In addition to the organizational behavior literature, a number of recent studies in financial economics are concerned with interlocking relationships between firms. For instance, a study of Australian firms reveals that company and individual director interlocks as well as board size have decreased since the mid eighties (Roy, Fox, and Hamilton, 1994). Booth and Deli (1996) report that when employees (not necessarily CEOs) of two different companies sit on each other's boards, the CEOs hold more outside directorships. Hallock (1997) finds that CEOs serving in any employee-interlocked firms earn higher salaries than they otherwise would. Like Hallock (1997), Core, Holthausen, and Larcker (1999) do not 
find any association between director interlock and total compensation. In contrast, Fich (2000a) reports positive associations between the number of interlocking directorships and the compensation that CEOs derive from executive stock options.

Cotter, Shivdasani, and Zenner (1997) study director interlocks between bidder and target firms. Their results suggest that the presence of director interlocks reduces the gains to target shareholders and decreases the likelihood that a target firm receives multiple bids. They indicate that interlocking directorships can affect target shareholder gains in at least two ways. First, interlocked directors have fiduciary obligations to the shareholders of both the target and the bidder, thus creating a conflict of interest. Second, such directors can ameliorate the information asymmetry between the interlocked bidder and target (but not necessarily with respect to other potential bidders) and may therefore dissuade other likely bidders from bidding. Fich (2000a) reports a negative association between the number of interlocking directorships and the probability of CEO turnover. These results suggest that interlocking directorates can create abuse if they endanger the independence of interlocked firms, decrease competition in the market for corporate control, exacerbate agency problems, or violate directors' fiduciary obligations as the agents of stockholders.

Results presented by Fich (2000b) indicate the absence of a relation between the number of CEO interlocks, or any employee interlock, and firm value as measured by Tobin's Q. These results suggest that interlocking relationships do not enhance the value of the firm and cast doubt on the extent to which firms use these relationships to improve their strategic objectives.

Recent studies provide some insight for understanding the reasons why CEOs accept outside directorship positions. Vancil (1987) maintains that as CEOs delegate authority to 
their likely successors, they free themselves to hold director positions with other firms. Booth and Deli (1996) argue that outside directorships do not represent unchecked perquisite consumption by CEOs. They find that CEOs of firms with growth opportunities hold fewer outside directorships and that CEOs are likely to hold more outside director positions as they transfer decision rights to their eventual substitute. Their research does not provide potential reasons for firms to interlock their CEOs.

All of these studies suggest that interlocking relationships between the boards of different companies warrant further scrutiny. In this study we attempt to explain why CEOs of different firms reciprocally interlock their boards by serving as directors on each other's boards.

\section{Theories and Hypotheses ${ }^{4}$}

\subsection{Board Reputation}

Fama (1980) views the board of directors as an important governance mechanism, arguing that the directors' concerns for their own reputation in the director labor market causes them to be effective monitors. ${ }^{5}$ Mace (1986) suggests that directorships can be a source of prestige and business contacts, which may induce board members to seek outside directorships. However, if there is an efficiently functioning market for managerial human

\footnotetext{
${ }^{4}$ As will be clear in the discussions of the data and results in Sections 4 and 5, in addition to the primary hypotheses advanced in the text below, we also include in our empirical testing a number of control variables, such as the size of the firm, the size of the board, characteristics of the CEO, etc.

5 Reputation considerations can be a double-edged sword, since directors could also develop a reputation for being "soft" in their monitoring of management, enticing some executives to seek them as directors. Other mechanisms, such as equity-based pay, must be put in place to assure that directors will fulfill their fiduciary responsibility and act in the best interests of the stockholders.
} 
capital, only the most experienced and effective directors would be invited to serve as directors on other boards.

Directors who have reputations as good monitors might be sought for service on many boards, and some studies have therefore used the number of additional board appointments as a measure of a director's quality. ${ }^{6}$ For these reasons boards whose members have larger numbers of other director obligations are likely to be perceived as being of high quality. This reputation for quality may extend to the firm's CEO, who has succeeded in assembling and presiding over the high-quality board. If this is the case, then CEOs from companies with highly reputable boards would be sought by other companies to serve as directors on their boards. Further, the CEOs of these other firms might also want to serve as directors on the highly reputable boards, either for personal reasons (e.g., to build personal prestige, develop contacts, etc.) or to enhance their productivity as CEOs of their "home" company. In line with previous studies, we use the total number of outside board obligations (directorships) of a given board as a proxy for the board's (or its directors') reputation. We utilize this variable to test the following hypothesis:

H1: The probability of reciprocal CEO interlocks increases in firms with highly reputable boards.

\subsection{CEO Compensation}

Berle and Means (1932) suggest that managerial ownership in large companies is too small to make managers interested in profit maximization. Jackson and Lazear (1991) and others have reported the benefits of deferred compensation, usually in the form of stock

${ }^{6}$ Evidence presented by Kaplan and Reishus (1990), Shivdasani (1993), and others support the view that the number of directorships may serve as an indicator of director reputation. 
options for retaining executives. They argue that stock-based compensation aids in the retention of executives because its payoffs are often deferred for a number of years into the future, requiring managers to stay with the firm and to make decisions that enhance the firm's long-run value in order to be able to receive payment. Hagerty, Ofer, and Siegel (1991) show that stock options can be especially effective at inducing far-sighted managerial behavior. Milgrom and Roberts (1992) argue that since the job performed by top management has a greater impact on overall firm performance, top management potential responsiveness to incentives is greater. Baker, Jensen, and Murphy (1988) assert that managers respond to the absence of incentives by taking "uneconomic actions."

All of these studies suggest that compensation contracts that include appropriate levels of deferred performance contingent pay should be effective in retaining highly qualified managers with the firms. The most utilized form of performance-contingent compensation for senior management is the executive stock option. Indeed, Yermack (1995) indicates that the lion's share of the CEO's compensation package results largely from variability in stock option awards. And Mehran and Yermack (1997) find an inverse and significant association between the probability of CEO turnover and the dollar value of stock option compensation that the CEO receives relative to his other compensation (i.e., basic salary and bonus).

Two characteristics of executive stock options are (1) that they augment base salaries with a call option and (2) executives are contractually restricted from exercising stock options for a specific period of time after the grant.

The first characteristic serves a dual purpose. On the one hand, the call option implies that managers' total compensation pattern is aligned with the compensation of 
shareholders. On the other hand, in order to augment the value of the call option managers should stay focused with their work on the firm and are less likely to look elsewhere for outside directorships. The second stock option characteristic also creates an important mechanism to keep valuable managers with the firm, since executives will have to wait before they are contractually allowed to exercise the options and cash in. Jensen and Murphy (1990) report the lack of strong pay-for-performance incentives for CEOs. If CEOs are not motivated enough to increase their firm performance they may seek additional compensation opportunities elsewhere.

This discussion suggests that CEOs who receive a significant amount of their pay from firm performance-contingent instruments would be less likely to seek or accept reciprocal interlocks with the chief executives of other firms. These conjectures lead to:

H2: The probability of reciprocal CEO interlocks decreases in companies where chief executives derive large fractions of their total remuneration from stock options.

The key explanatory variable that we use to test $H 2$ is the fraction of the CEO's total compensation that comes from executive stock options. The numerator has the value of the new stock options the CEO receives when granted during the year; the denominator encompasses the total compensation of the $\mathrm{CEO}$, including his regular salary, bonus, fringe benefits, and the value of the options.

The value of new stock options when granted during 1991 is computed assuming that the prevailing stock price equals the option's exercise price ${ }^{\square}$ and is calculated using the Black-Scholes (1973) methodology, adjusted for dividend payouts (Merton,1973), which is:

\footnotetext{
${ }^{7}$ In the calculations it is assumed that the underlying stock price at the time of the award equals the exercise price of options, because almost all firms set the exercise price equal to the current stock price (see, e.g., Smith and Zimmerman, 1976; Yermack, 1995). The average yield on 10-year U.S. Treasury bonds during the last month of the year is used for the interest rate. Finally, a maturity time of 10 years for the options is assumed, since this is
} 


$$
\begin{aligned}
& \text { optval }=\mathrm{N}\left[\mathrm{Pe}^{-\mathrm{dT}} \Phi(\mathrm{Z})-\mathrm{Ee}^{-\mathrm{rT}} \Phi\left(\mathrm{Z}-\sigma(\mathrm{T})^{1 / 2}\right)\right] \\
& \mathrm{Z}=\left[\ln (\mathrm{P} / \mathrm{E})+\mathrm{T}\left(\mathrm{r}-\mathrm{d}+\sigma^{2} / 2\right)\right] /\left[\sigma(\mathrm{T})^{1 / 2}\right]
\end{aligned}
$$

where

$\mathrm{N}=$ Number of shares represented by the stock option award

$\mathrm{P}=$ Price of underlying stock at the end of the year

$\mathrm{E}=$ Average exercise price of the stock options granted

$\mathrm{d}=\log (1+$ dividend rate/price at the end of the year $)$

$\mathrm{r}=\log (1+$ year-end interest rate $)$

$\Phi=$ Cumulative probability function (normal distribution)

$\sigma=$ Expected stock return volatility over life of option

$\mathrm{T}=$ time to expiration

\subsection{Board Activity}

The board of directors of a major corporation should meet regularly in order to monitor and discuss the various activities of the firm. Vafeas (1999) finds that increasing board meeting activity sends a negative signal to the market. He finds that firms whose boards meet more frequently are less valued by the market. Lipton and Lorsch (1992) maintain that the most widely shared problem that directors confront is a lack of time to carry out their duties. Shivdasani and Yermack (1999) argue that the benefits of outside directorship levels could be non-linear, declining for the highest directorship levels as busy directors might have less available time to attend other board meetings and properly monitor the activities of other firms.

These studies suggest that increasing board activity may dissuade CEOs from seeking reciprocal interlocks with their counterparts whose companies have active boards. This lack of interest might arise because increasing board activity could be a signal of bad

the duration for the majority of CEO awards and the limit imposed by the IRS for options to receive favorable tax treatment (see Matsunaga, 1995). 
news for the firm (Jensen, 1993) or simply because the directors are expected to monitor aggressively the activities of the firm. In addition, if a CEO's "home" board is more active (as evidenced by more meetings), that CEO may have less free time and therefore be less inclined (e.g., because of less free time) to seek directorships on other boards. These arguments lead us to:

H3: The probability of reciprocal CEO interlocks decreases in firms with greater board meeting activity.

Board meeting activity is measured as the actual number of board meetings per year that firms report in their proxy statements. This variable includes all meetings of the board of directors during the fiscal year, including regular and special meetings, but not telephone meetings or action by written consent.

\subsection{Equity Ownership}

Academics have long noted that low levels of managerial stock ownership encourage agency problems. As argued by Berle and Means (1932) as well as by Jensen and Meckling (1976), when managers own little equity ownership and stockholders are diffuse, managers may deviate from stockholder value maximization and instead embrace self-gain policies. Significant amounts of equity ownership have long been identified as an effective mechanism to align the incentives of managers with those of their shareholders and thus entice managers to embrace value-maximizing projects for the benefit of shareholders. To the extent that a CEO's outside directorships represent time and effort that he undertakes because of personal gain and that divert him from his primary responsibilities,, we are led to the following hypothesis:

${ }^{8}$ Brown and Bacon (1974) suggest a number of reasons why a CEO might join other 
H4: The probability of a reciprocal CEO interlock decreases with larger amounts of equity ownership by the CEO.

To test this hypothesis we use the CEO's fractional ownership of the firm as an independent variable in our econometric analysis. The numerator of this variable is the number of shares owned by the CEO and or his/her immediate family. The denominator is the total number of the firm's shares that are outstanding.

\subsection{Number of CEOs on a Company's Board}

The presence of another company's CEO on a company's board already provides the first link of a potential reciprocal CEO interlock. Further, that CEO's presence may encourage reciprocation, for a number of potential reasons: First, the reciprocal interlock may strengthen any strategic links between the two companies. Second, the two individuals may recognize the opportunities for mutual support on each other's board (i.e., mutual "back scratching"). Third, the two may simply come to appreciate and be comfortable with each other. These arguments lead us to the following:

H5: The likelihood of the formation of a reciprocal CEO interlock increases with a larger number of CEOs of other companies who serve on a company's board of directors.

We test this hypothesis by including in our models the number of CEOs of other companies that serve as outside directors on a company's board as an explanatory variable.

In addition to our five primary hypotheses, we also implicitly test a number of lesser hypotheses by including control variables in our regressions, which involve variables encompassing the firm's characteristics (e.g., the firm's total assets, Tobin's Q, whether the

boards. Booth and Deli (1996) directly test hypotheses concerning the numbers of outside directorships held by CEOs. 
firm is a bank), the board's characteristics (e.g., size of board, board compensation), and the CEO's characteristics (e.g., the CEO's age and tenure).

\section{Sample Selection, Data Description, and Summary Statistics}

The estimations reported below rely on our examination of a data set that provides board composition, compensation, and other company information for firms during the 1991 proxy season. ${ }^{6}$ The data set includes information on board and director characteristics, firm performance, and other company attributes for all the companies in the set.

To qualify for inclusion in the sample, a firm is required to rank among Forbes magazine's largest 500 U.S. companies in any of the categories of total assets, market capitalization, sales, or net income. ${ }^{10}$ For each firm, compensation data were collected and arranged from the corporation's SEC proxy, 10-K, and 8-K filings. Data on board and ownership structure and operational and stock market performance were also collected and classified for all companies in the sample. Further, for each of the firms in the sample, data on their board composition was gathered and organized. Each director is assigned a classification according to his/her principal occupation. Full-time employees of the company are designated as inside directors. Those individuals who are closely associated with the firm -- for example those who are relatives of corporate officers, lawyers,

\footnotetext{
${ }^{9}$ We wish to thank David Yermack and Kevin Hallock for graciously sharing their data with us.

10 The Forbes 500 data set has been used as the source of firms for the investigation of a number of other corporate governance questions; see, for example, Murphy (1985), Murphy and Zimmerman (1993), Yermack (1995), Hallock (1997), and Vafeas (1999). As a partial test for large-firm bias, we split the sample in half by size of firm, and re-ran the basic regressions of Section 5 using the two sub-samples of larger and smaller firms. The same results emerged for the two sub-samples as is reported for our overall sample, and an F-test indicated the absence of a significant difference between the two sub-sample estimations.
} 
consultants, or those who have substantial business relationships with the company -- are designated as "gray" directors. Outside directors are those who do not have either inside or gray status.

The data set includes the name of the firm for which he/she serves as director, full name and occupation, principal employer, and whether he or she is retired. The data cover 9,804 director seats held by 7,519 individuals. There are fewer individuals than seats since some directors are members of more than one board. When necessary the data from annual reports and proxy statements were supplemented with information from the Million Dollar Directory, Standard \& Poor's Register of Corporations, the Directory of Corporate Affiliations, Who's Who in Finance and Industry, the Lexis-Nexis System, and Laser Disclosure.

The final data set analyzed consists of the 610 firms for the 1991 proxy season for which complete data could be gathered from these sources, supplemented by operational data gathered from COMPUSTAT and stock market performance data obtained from the Center for Research on Securities Prices (CRSP).

We present some sample descriptive statistics in Table 1. These data encompass CEO, board, and company attributes. The mean board size of 13.05 in our sample is comparable to the board sizes of 12.62 reported by Booth and Deli (1996) for 1989-1990 and 12.30 reported by Klein (1998) for 1992-1993 data. The mean tenure of a CEO as CEO reported in our Table 1 (8.62) is similar to the CEO tenure (8.4) reported by Booth and Deli (1996). And the mean number of board meetings (8.32) reported in Table 1 is comparable to the board meetings (7.45) reported by Vafeas (1999) for 1990-1994. 
Table 2 presents statistics on the incidence of reciprocal CEO interlocks in our sample. Eighty-seven firms, or $14.2 \%$ of the firms in the sample, have at least one reciprocal CEO interlock relationship. Of these 87 firms, most (72 firms) have only one reciprocal CEO interlock.

In Table 3 we present the simple means of the CEO, board, and company variables for the firms that have at least one reciprocal CEO interlock and also for those that have none, along with the results of t-tests on the differences in means between the two groups. As can be seen, the differences in sub-sample means are statistically significant (at a $10 \%$ or better level) for 13 variables. With respect to our primary hypotheses discussed in Section 3 , there is a large and quite significant positive difference between the mean number of outside directorships held by the board members of a company with a reciprocal CEO interlock and by the board members of a company that has none, 11 consistent with $H 1$. With respect to $H 2$, the mean of the fraction of the CEO's total compensation that is received in the form of stock options is larger for the companies with reciprocally interlocked CEOs than for the companies without interlocked CEOs, but the difference is not significant. With respect to $H 3$, the mean of the number of board meetings is smaller for the companies with reciprocally linked CEOs than for the companies without interlocked CEOs, but the difference is not significant. As for $H 4$, the stock ownership in the firm of a CEO who is part of a reciprocal interlock is significantly smaller than is true for a CEO who is not part of a reciprocal interlock, which is consistent with our conjecture. Finally, with respect to $H 5$, the number of CEOs on the boards of companies with reciprocal CEO interlocks is

11 The simple Pearson correlation coefficient between the presence of at least one reciprocal CEO interlock for a company and the board reputation variable is 0.40 . 
significantly larger than is true for companies without such interlocks, which again is consistent with our conjecture.

In addition, significant positive differences are found with respect to the means of the CEO's salary and bonus, the CEO's age, the CEO's tenure in the firm, the board size, the number of outside directors, the number of all reciprocal company interlocks, the director's retainer fee, and firm size. Significant negative differences in means are found for the CEO as a member of the founding family and for the bank indicator. This last result may be part of the effect found by Kroszner and Strahan (1999), whereby banks are reluctant to have interlocks with companies that may become financially troubled; or it may simply be an indication of the additional regulatory pressures that are placed on banks, which may leave bank CEOs with less free time for outside directorships.

Simple bivariate comparisons, of course, may not reveal the complete statistical story, because of the parallel and confounding influences of key variables. Consequently, we now turn to our multivariate analyses.

\section{Multivariate Analyses and Results}

For all of our analyses, our unit of observation is a company (in 1991) and its CEO, board, and company characteristics are the relevant variables.

\subsection{Simple Probit and Step Probit Models}

To test our hypotheses we first construct an indicator variable that takes the value of zero if a company is not part of a reciprocal CEO interlock and the value of one otherwise. 
We use this $(0,1)$ indicator variable as the dependent variable in the estimation of the following probit model:

Probability (occurrence of reciprocal CEO interlock) $=f$ (board reputation, fraction of the CEO pay coming from stock options, number of board meetings, Tobin's $Q, C E O$ tenure with the firm, the number of CEO-directors on the board, the fractional equity ownership of the CEO in the firm, and other [control] variables).

To account for industry effects, we include as independent variables a set of $(0,1)$ dummy variables representing the primary two-digit SIC industry of each firm. 12

The probit analysis just described simply registers the presence or absence of one or more reciprocal CEO interlocks on a company's board. As indicated in Table 2, 72 companies in our sample have a single reciprocal CEO interlock, 12 firms experience two reciprocal CEO interlocks, and three firms experience three reciprocal CEO interlocks. To incorporate this greater completeness of information about these multiple interlocks (and because the number of reciprocal CEO interlocks cannot be less than zero and thus this variable is left-hand censored) we also estimate a step probit model that includes the actual count (rather than just the presence) of reciprocal CEO interlocks for each firm as the dependent variable. The same explanatory variables appear in this regression as in our probit model.

\subsection{Empirical Results}

12 The aggregate group of industry dummy variables does not pass an F-test for significance, and their presence does not change the coefficient values or significance levels appreciably. Nevertheless, for completeness, both the simple probit and the step probit regressions shown in Table 4 include the industry dummy variables as (unreported) explanatory variables. 
The results of our simple probit and step probit regressions are presented in Table 4. As can be seen, the results of the two models -- in terms of the magnitudes of coefficients and levels of statistical significance -- are quite similar.

The most significant explanatory variable in both regressions is the reputation of the company's board, as proxied by the number of outside directorships held by that company's directors. 14 It is worth noting that the board size itself is one of the control variables and is not significant.

This strong positive relationship between a firm's involvement in a CEO reciprocal interlock and the external involvement of its board provides strong support for our first hypothesis. CEO's do seem to want to associate with "classy" boards, and a CEO who has succeeded in assembling a "classy" board is more desirable as a member of other companies' boards. 15

Another significant variable in our analyses is the fraction of the CEO's total annual remuneration that comes in the form of stock options. The larger is this fraction, the less likely is the CEO (and thus the company) to be involved in a reciprocal CEO interlock. The absolute size of the CEO's remuneration is controlled for by the inclusion of the CEO's base salary and bonus as an explanatory variable; it is not significant.

${ }^{13}$ Since (as Table 3 indicates) we have incomplete data for some of the companies among the 610 in our sample, the regressions in Table 4 involve 603 observations on the companies for which complete data are available.

${ }^{14}$ We also tried an alternative version of a board reputation variable: the average number of outside directorships held by the company's board members. The regression results were qualitatively the same as those reported.

15 A somewhat different, though consistent interpretation of our result would be that a company that has a corporate culture of its directors' holding outside positions would likely involve the CEO in this culture as well. Core et al. (1999) question the efficiency of directors who serve on multiple boards. Thus, this positive association between reciprocal CEO interlocks and outside board positions by the CEO's board may be an indication that this inefficient culture encourages an inefficient practice by the company's CEO. 
This negative association between the stock-option fraction of total remuneration and the likelihood of the CEO's involvement in a reciprocal CEO interlock is support for our second hypothesis. A CEO that will be richly rewarded from a strong performance of his company is less likely to be seeking outside directorships, including reciprocal CEO interlocks.

A third significant variable is the annual number of board meetings. Larger numbers of meetings are associated with a lower probability of a reciprocal CEO interlock. The magnitude of the directors' fees is also included as an explanatory variable, but is not significant.

The inverse relationship between the numbers of meetings and the probability of a reciprocal CEO interlock is support for our third hypothesis. More meetings may keep a CEO more involved "at home" and mean less time for outside involvements; or the time commitment of more meetings may deter a CEO from another company from becoming a director; or more meetings may be indicative of company difficulties, which another company's CEO may want to avoid.

Our fourth hypothesis -- that reciprocal CEO interlocks should be negatively associated with the CEO's ownership position in his firm -- is not as strongly supported by our multivariate analyses. Though the signs of this variable are negative in both regressions, neither coefficient attains even a $10 \%$ significance level. This result is contrary to the result of our univariate analysis, which showed a significantly smaller ownership position by the CEOs who were involved in reciprocal interlocks than was true for the CEOs without reciprocal interlocks. However, the CEO ownership variable is strongly and positively 
correlated with the tenure of the CEO as $\mathrm{CEO} \sqrt{16}$ and with the $\mathrm{CEO}$ as founder, $\frac{17}{\text { as well as }}$ showing lesser levels of association with the other explanatory variables. $\frac{18}{1}$ These other influences may be confounding and weakening the underlying negative relationship between reciprocal CEO interlocks and CEO ownership.

Similarly, our fifth hypothesis -- that reciprocal CEO interlocks should be positively associated with the number of CEOs of other firms that are on a company's board -- is not as strongly supported by our multivariate analyses. Again, the signs for the variable are as predicted -- positive -- but the coefficients are not significant; by contrast, the univariate analysis showed that there were a significantly larger number of outside CEOs on the board of a reciprocally interlocked CEO than was true for the board of a CEO that was not reciprocally interlocked. And again, correlations with other explanatory variables may be part of the reason why the underlying positive relationship fails to hold in the multivariate analyses.

\footnotetext{
${ }^{16}$ The Pearson correlation coefficient is +0.35 .

${ }^{17}$ The Pearson correlation coefficient is +0.45 .

${ }^{18}$ When the CEO ownership variable is regressed against all of the other explanatory variables in a separate OLS regression, the $R^{2}$ is 0.30 .

19 The number of other companies' CEOs that are on a company's board is strongly and positively associated with the size of the board $(\mathrm{r}=+0.46)$ and with the outside directorships held by that company's board members $(\mathrm{r}=+0.44)$. When the number of outside CEOs on a company's board is regressed against all of the other explanatory variables in a simple OLS regression, the $\mathrm{R}^{2}$ is 0.32 . The strong positive association between the number of outside CEOs on a company's board and the outside directorships held by that company's board members raises another possible explanation for the lack of significance of the CEO variable in the multivariate context: CEOs from other companies may want to join a board, so as to be able to associate with its "classy" members; but the CEO of that company may not feel as strongly about reciprocating.
} 
There are a few other variables that are significant and that are worthy of discussion. First, the firm's Tobin's $\mathrm{Q}^{20}$ is positively associated with the probability of a reciprocal CEO interlock. A larger Tobin's Q is likely to be indicative of a highly valued firm with more growth opportunities. Alternatively, the higher Tobin's Q may indicate greater intangible assets of the senior management of the firm (Morck, Shleifer, and Vishny, 1989). For either reason, other CEOs may want to be associated with such a firm, and other companies may want this firm's CEO to add luster to their boards.

Second, the CEO's tenure with the firm is positively associated with the probability of a reciprocal CEO interlock. The longer that a CEO is with a company, especially as a senior manager, the greater will be the opportunities that he will have to meet senior managers (and potential or actual CEOs) of other large firms and (through natural selection) the more likely is he to gain a favorable reputation, for himself and for his company. Both effects of longevity would encourage the formation of reciprocal CEO interlocks. 2.2

\footnotetext{
${ }^{20}$ Tobin's $\mathrm{Q}$ is defined as the market value of the firm's assets divided by the replacement costs of the assets. We follow Yermack (1996) in using the recursive methodology proposed by Perfect and Wiles (1994) for valuing debt, inventory, and fixed assets. The market value of assets is computed by adding the estimated values of the components of total liabilities and stockholders' equity. Recursive algorithms that take into account the effect of inflation, real depreciation rates, capital expenditures, and the method of inventory valuation used by each company are used to estimate the replacement costs of inventories and fixed assets. Other assets are assumed to have replacement costs equal to book values (Yermack 1996).

21 Booth and Deli (1996) find a negative relationship between the number of outside directorships held by a CEO and the market-to-book ratio of the company's assets. They interpret their result as an indication that, for firms with greater growth opportunities, the opportunity costs of the CEO's holding outside directorships are larger. It is worth noting that our Tobin's Q variable is different from their market-to-book variable and also that we measure reciprocal CEO interlocks and not just the number of outside directorships held by a CEO.

${ }^{22}$ We did not, however, find a significant relationship between reciprocal CEO interlocks and the CEO's tenure as CEO. The last result differs somewhat from that of Booth and Deli
} 
Third, the bank indicator variable is negative in both regressions and is significant in the step probit regression. 23 The multivariate analysis thus supports the univariate conclusions: The CEOs of banks do seem to be more reluctant to participate in reciprocal interlocks than are their counterparts at other firms, either because of regulatory pressures or their fears of conflict-of-interest claims.

The remaining control variables did not yield significant coefficients. Because a few of these variables did show significant results in the univariate differences in means, they are worthy of some discussion. First, the size of the firm itself, as measured by total assets, did yield positive coefficients (consistent in direction with the univariate comparison), but neither was significant. ${ }^{24}$ Second, as noted above, the size of the board is insignificant, and the coefficients vary in sign in the two regressions. By contrast, in the univariate analysis, the firms with reciprocally linked CEOs had significantly larger boards. Third, and perhaps surprisingly, though the presence of other (outside) CEOs on a company's board does yield positive coefficients in both regressions (consistent in direction with the univariate comparison), those coefficients are not significant. ${ }^{2.5}$

(1996), who find a significant positive association between the number of outside directorships that a CEO holds and his tenure as CEO. They interpret their result as support for Vancil's (1987) process of CEOs' transferring responsibilities to their successors as their tenure as CEO lengthens, which thereby reduces the cost to the company of the CEO's taking an outside directorship.

${ }^{23}$ This negative effect is present even though the set of two-digit SIC dummy variables includes a separate variable for all financial institutions. When the regressions are estimated without the inclusion of the industry dummy variables, the same results hold: the bank variable remains negative in both regressions and is significant in the step probit regression.

${ }^{24}$ Other measures of firm size, such as the natural log of sales, were also tried, yielding similar absences of significant effects.

${ }^{25}$ To check for robustness, a number of other explanatory variables -- such as the composition of the board, the age of the CEO, the annual return on assets of the company, 


\subsection{Further Controls}

\subsubsection{Strategic Interactions}

Relationships between firms may evolve in order to reduce contracting costs between two parties. Firms may interlock corporate boards to improve or solidify their contracting relationships. For instance, a firm may want to have a customer on their board and/or to place one of its executives on the customer's board. If the firm is very dependent on the particular contracting relation that it has with the other party, it may wish to have its CEO as a member on that other firm's board. In addition to the possible strategic advantage a firm may acquire by a board interlock, Booth and Deli (1996) argue that asymmetry of information is reduced for the buyer (supplier) when she is a member of the supplier's (buyer's) board.

These assertions lead us to identify as an empirically testable question the use of interlocking relationships as a tool for enhancing the strategic objectives of firms.

\subsubsection{CEO's Influence}

The results presented in Table 4 support our hypothesis suggesting that the probability of reciprocal CEO interlock increases in firms where CEOs do not derive large fractions of their total compensation from stock options. It is clear that if this is the case the CEOs will promote and work toward the formation of reciprocal interlocks. One clear way that a CEO would have in helping promote reciprocal interlocks is by serving on the board's nominating committee. Shivdasani and Yermack (1999) show that the

etc. -- were tried in these regressions, with insignificant results and with no change in the main results reported above. 
quality of director appointments diminishes when the CEO is involved in the appointment of the new directors. In fact, they show that market reactions are significantly lower when the CEO is in the nominating committee and involved in the appointment than when the CEO is not.

In the context of our investigation we identify the relationship between a CEO's serving on the board's nominating committee and the presence of CEO interlocks as another open empirical question.

\subsubsection{Results}

For 350 firms in our sample we are able to obtain information on its nominating

committee. ${ }^{6}$ In this reduced sample there are 71 firms that have a reciprocal interlocking relationship between CEOs. These interlocks are again used as the dependent variable in our analysis. As an additional explanatory variable we use a $(0,1)$ indicator to identify the absence or presence of the firm's CEO in the committee. We use this indicator variable to test the effect, if any, that a CEO serving in the nominating committee may have on the formation of reciprocal interlocks.

All firms in our reduced sample have at least one CEO as an outside director (though only 71 are involved in an interlocking relationship). For all 350 firms we construct a $(0,1)$ indicator variable to identify the outside CEOs that are gray directors (i.e., that may be from a supplier or customer firm). The variable equals 0 if an outside CEO director is not gray, and is equal to 1 otherwise. We define this variable as a

${ }^{26}$ We wish to thank April Klein for graciously sharing her nominating committee data with us. 
"strategic objectives" indicator and use it to test if firms use reciprocal interlocking relationships as a device to improve their strategic objectives.

Table 5 presents the results of our estimation using the reduced sample of 350 firms. We estimate a simple probit model since the maximum number of reciprocal CEO interlocks that any firm in this sample has is one. The first column in Table 5 repeats the analysis we performed in the first column of Table 4. The second column expands the analysis by including the $(0,1)$ indicator variable for strategic objectives and the $(0,1)$ indicator variable that identifies the absence or presence of the CEO on the board's nominating committee.

The overall results presented in Table 5 are in agreement with our results in Table 4. Reciprocal CEO interlocks are less likely to be formed if CEOs receive large fractions of their total pay from stock options, less likely to occur in firms whose boards meet more frequently, less likely to arise in banks, and more likely to occur in highly reputable boards. In the second column of Table 5 we address the two open empirical questions that are identified in this section. We note that the CEO-on-the-nominating-committee $(0,1)$ variable is positive and significant. This result is consistent with the notion that a CEO's intervention in the nominating process promotes the formation of reciprocal interlocks.

Our strategic objective $(0,1)$ indicator variable is not significant. ${ }^{27}$ This result may indicate that the desire to have a supplier or a buyer on one's board does not

${ }^{27}$ We also replaced the strategic objective $(0,1)$ indicator variable by the number of outside gray CEOs divided by the total number of outside CEOs. This variable was also not significant. 
necessarily promote or increase the likelihood of the formation of a reciprocal interlocking relationship between CEOs. 8

\section{Conclusion}

The board of directors of a public corporation represents a key mechanism for monitoring managers and making important financial decisions. The composition of boards of directors is an important component of a system of corporate governance. Increased knowledge about the determinants of that composition can further the understanding of corporate governance structures.

We start by noting that the reciprocal interlocks of CEOs on the boards of large corporations -- situations where the CEO of company $i$ is on the board of company $j$ and the CEO of company $j$ is on the board of company $i$-- occur in a non-trivial number of instances: in 1991 about one large company in seven was involved in a reciprocal interlock of this type. We are unaware of any previous efforts to explain this phenomenon. We next offer some hypotheses as to the circumstances that may encourage or discourage such reciprocal interlocks. We conjecture that reciprocal CEO interlocks are (a) more likely when a board has more outside directorships, (b) less likely when a CEO has more of his total annual compensation paid in the form of stock options, (c) less likely when a company's board is more active and holds more meetings, (d) less likely when a CEO has a larger ownership share of his company, and (e) more likely when there are more CEOs from other companies as outside directors on a CEO's board.

\footnotetext{
${ }^{28}$ Our definition of "gray" includes not only those individuals that have commercial relationships with the firm, but also those directors who are relatives of the firm's officers. It is possible that this errors-in-variables situation precludes us from measuring the full impact that business relationships among firms have in promoting reciprocal
} 
We test these hypotheses on a sample of 610 large corporations in 1991, using company, board, and CEO characteristics as control variables. Using simple probit and step probit models, we find significant statistical support for the first three of our hypotheses but not the fourth and fifth (although our univariate analysis does provide support for the latter two). We also find significant positive relationships between the probability of a reciprocal CEO interlock and the Tobin's Q of a company and the tenure of the CEO with the company, and we find an inverse and significant relationship in the step probit analysis between the probability of a reciprocal CEO interlock and whether the CEO's firm is a bank. Further, for a smaller (but consistent) sample we find that the presence of the CEO on the nominating committee is a significant positive influence on the likelihood of reciprocal interlocks, but we do not find that reciprocal interlocks are used to advance the strategic objectives of the firm.

By showing that reciprocal CEO interlocks are not random phenomena but have significant determinants, our results may help address some of the controversies surrounding interlocking directorates. Advocates of such arrangements argue that the interlocks are beneficial, particularly if they promote less costly monitoring, help mobilize private information, or economize on scarce managerial resources. In such instances, interlocking relationships can promote efficiency and increase shareholders' wealth. In contrast, opponents of such arrangements see them as promoting cronyism, exacerbating agency problems, and potentially reducing competition in the market for corporate control, thereby reducing efficiency and stockholders' wealth. Though our results do not settle this dispute, they do show its relevance, since we find that this powerful form of interlock -- the reciprocal CEO interlock -- is significant and purposive.

interlocking relationships between their CEOs. 
Further, our results shed some direct and indirect light on the consequences of reciprocal CEO interlocks for shareholder wealth. As noted above, we find a significant positive association between CEO reciprocal interlocks and the CEO's involvement in the selection of directors; since Shivdasani and Yermack (1999) find negative market reactions to director appointments when CEOs are involved in the selection of new directors, a likely negative market reaction to CEO reciprocal interlocks seems reasonable as well. Further, we do not find that CEO reciprocal interlocks occur in a way that might advance the strategic objectives of the firm. Also, the negative association between stock option compensation and CEO reciprocal interlocks may indicate that inadequate performancelinked compensation may cause the CEO to divert some of his attention to the activities of another company, at the expense of his "home" company's shareholders. The positive association between the outside directorships of a company's board and CEO reciprocal interlocks may indicate that a "classy" board membership is a magnet for other CEOs; but the prevalence of outside directorships may also mean that the company's affairs do not receive adequate board attention, and this inefficient culture encourages the CEO similarly to divert his attention to other companies' boards. In addition, we find that banks are reluctant to become a party to CEO reciprocal interlocks, perhaps for the reasons suggested by Kroszner and Strahan (1999). Finally, though we find a positive association between CEO reciprocal interlocks and Tobin's $\mathrm{Q}$, we cannot tell whether it is a company's higher $\mathrm{Q}$ that attracts the reciprocal CEOs or whether their presence is a contributing factor to the higher Q.

Our research concerning reciprocal CEO interlocks has examined this phenomenon primarily from the perspective of a single company, and its board and CEO, that is a party to 
such a relationship. Although we do not find evidence consistent with the notion that such relationships might serve as a means of enhancing the strategic objectives of firms, future investigations could build on our results to explore this issue further. We believe that such research, along with the results presented in this paper, can widen the understanding of this significant aspect of board composition and corporate governance. 


\section{References}

Bacon, J., Brown, J., 1974. Corporate directorship practices: Role, selection and legal status of the board. Joint Research Report from the Conference Board and the American Society of Corporate Secretaries, Inc. New York, NY.

Baker, G.P, Jensen, M., Murphy, K., 1988. Compensation and incentives: practice vs. theory. The Journal of Finance, 43 (3), 593-616.

Berle, A., Means, G., 1932. The Modern Corporation and Private Property. Macmillan, NY.

Black, F., Scholes, M., 1973. The pricing of options and corporate liabilities. Journal of Political Economy, 81, 637-659.

Booth, J., Deli, D., 1996. Factors affecting the number of outside directorships held by CEOs. Journal of Financial Economics, 40, 81-104.

Core, J., Holthausen, R., Larcker, D., 1999. Corporate governance, chief executive officer compensation, and firm performance. Journal of Financial Economics, 51, 371-406.

Cotter, J., Shivdasani, A., Zenner, M., 1997. Do independent directors enhance target shareholder wealth during tender offers? Journal of Financial Economics 43, 195-218.

Dooley, P., 1969. The interlocking directorate. American Economic Review 59-3, 314-323.

Fama, E., 1980. Agency problems and the theory of the firm. Journal of Political Economy 88, 288-103.

Fich, E., 2000a. CEO compensation and turnover in mutually interlocked boards. Working Paper, Kenan-Flagler Business School, UNC - Chapel Hill. Chapel Hill, NC.

Fich, E., 2000b. Do directors who are CEOs of other firms enhance firm performance? Working Paper, Kenan-Flagler Business School, UNC - Chapel Hill. Chapel Hill, NC.

Hagerty, K., Ofer, A., Siegel, D., 1991. Managerial compensation and incentives to engage in far-sighted behavior, Working Paper, Northwestern University.

Hallock, K., 1997. Reciprocally interlocking boards of directors and executive compensation. Journal of Financial and Quantitative Analysis 32-3, 331-344.

Jackson, M.O., Lazear, E.P., 1991. Stocks, options and deferred compensation. Research in Labor Economics, 12, 41-62.

Jensen, M., 1993. The modern industrial revolution, exit, and the failure of internal control systems. The Journal of Finance 48, 831-880. 
Jensen, M.C., Meckling, W.H., 1976. Theory of the firm: Managerial behavior, agency costs and ownership structure. Journal of Financial Economics 3, 305-360.

Jensen, M.C., Murphy, K.J. 1990. Performance pay and top-management incentives, Journal of Political Economy, 98-2, 225-264.

Kaplan, S., Reishus, D., 1990. Outside directorships and corporate performance. Journal of Financial Economics 27, 389-410.

Klein, A. 1998. Firm performance and board committee structure. The Journal of Law \& Economics 41, 275-303.

Kracaw, W.H., Zenner, M., 1998. Bankers in the boardroom: Good news or bad news? Working Paper, The Kenan-Flagler Business School, The University of North Carolina, Chapel Hill, NC.

Kroszner, R., Strahan, P., 1999. Bankers' role in corporate governance. In Global Financial Crises: Implications for Banking and Regulation. Federal Reserve Bank of Chicago, 35th Annual Conference on Bank Structure and Competition, May, 242-254.

Lipton, M., Lorsch, J., 1992. A modest proposal for improved corporate governance. Business Lawyer 48, 59-7.

Mace, M., 1986. Directors: Myth and Reality. Harvard Business School Press, Boston, MA.

Matsunaga, S.R., 1995. The effects of financial reporting costs on the use of employee stock options. Accounting Review 70, 1-26.

Mehran, H., Yermack, D., 1997. Compensation and top management turnover. Working paper, Stern School of Business, New York University. New York, NY.

Merton, R.C., 1973, Theory of rational option pricing, Bell Journal of Economics and Management Science, 4, 141-183.

Milgrom, P., Roberts, J., 1992. Economics, Organization and Management, Prentice-Hall, Englewood Cliffs, NJ.

Mizruchi, M., Stearns, L., 1988. A longitudinal study of the formation of interlocking directorates. Administrative Science Quarterly 33, 194-210.

Morck, R., Shleifer, A., Vishny, R., 1989. Alternative mechanisms for corporate control. The American Economic Review 79-4, 842-852.

Murphy, K., 1985. Corporate performance and managerial remuneration: An empirical analysis. Journal of Accounting and Economics, 7, 11-42. 
Murphy, K., Zimmerman, J., 1993. Financial performance surrounding CEO turnover. Journal of Accounting and Economics, 16, 273-315.

National Association of Corporate Directors, 1996. NACD Blue Ribbon Commission Report on Director Professionalism.

Palmer, D., 1983. Broken ties; interlocking directorates and intercorporate coordination. Administrative Science Quarterly 28, 40-55.

Perfect, S.B., Wiles, K.W., 1994. Alternative construction of Tobin's Q: An empirical comparison. Journal of Empirical Finance, 1, 313-341.

Pettigrew, A., 1992. On studying managerial elites. Strategic Management 13, 163-182.

Pfeffer, J., 1972. Size and composition of corporate boards of directors. Administrative Science Quarterly, 17, 218-228.

Roy, M., Fox, M., Hamilton, R., 1994. Board size and potential corporate and director interlocks in Australasia. Australian Journal of Management 19-2, 201-212.

Schoorman, F., Bazerman, M., Atkin, R., 1981. Interlocking directorates: A strategy for reducing environmental uncertainty. Academy of Management Review 6, 243-251.

Shivdasani, A., 1993. Board composition, ownership structure, and hostile takeovers. Journal of Accounting and Economics 16, 167-198.

Shivdasani, A., Yermack, D., 1999. CEO involvement in the selection of new board members: an empirical analysis. Journal of Finance, 54-5, 1829-1853.

Smith, C.W., Watts, R.L., 1992. The investment opportunity set and corporate financing, dividend, and compensation policies. Journal of Financial Economics, 32, 263-292.

Smith, C.W., Zimmerman, J.L., 1976. Valuing employee stock option plans using option pricing models. Journal of Accounting Research, 14, 357-364.

Vafeas, N., 1999. Board meeting frequency and firm performance. Journal of Financial Economics 53, 113-142.

Vancil, R., 1987. Passing the baton: Managing the process of CEO succession. Harvard Business School Press. Boston, MA.

Yermack, D., 1995. Do corporations award CEO stock options effectively? Journal of Financial Economics, 39, 237-269.

Yermack, D., 1996. Higher market valuation of companies with a small board of directors. Journal of Financial Economics, 40, 185-211. 
Table 1

\section{Sample Statistics}

The sample consists of 610 annual observations for 1991. A firm is included in the sample if Forbes Magazine ranked it as one of the 500 U.S. largest public companies during the year on any of four criteria: total assets, market capitalization, sales, or net income. A reciprocal CEO interlock occurs when the CEO of firm i serves as a director of firm $\mathrm{j}$ and the CEO of firm $\mathrm{j}$ serves as a director of firm i. A reciprocal company interlock occurs when any current or retired employee from firm i (including the CEO) sits of firm's j's board and any current or retired employee from firm $\mathrm{j}$ (including the CEO) sits on firm's i's board. Board size represents the number of board directors, as listed in the proxy statement as of the annual meeting date during the fiscal year. Inside directors are those who are current of former officers of each firm. Gray directors are those who are relatives of corporate officers, or those who have a substantial business relationship with the firm, either personally or through their principal employers. Outside directors are those who have neither inside nor gray status. Director fees include annual retainers and fees paid for regular and special board meetings during the fiscal year. The number of board meetings per year reports meetings of the board of directors during the fiscal year, including regular and special meetings, but not telephone meetings or action by written consent. The value of stock options granted consists of new stock options (including stock appreciation rights) granted during the year, adjusted for stock splits calculated using the BlackScholes (1973) formula. The CEO-from-founding-family dummy variable equals 1 if is a member of the company's founding family or if the CEO is a member of a family that acquired control of the firm. Tobin's Q is the market value of assets divided by the replacement value of the assets. The bank $(0,1)$ indicator is a variable that takes the value of one if the company is a bank and takes the value of zero otherwise. Board reputation is measured by the number of outside directorships held by the company's board members.

Variable

\section{CEO Characteristics}

CEO's salary and bonus (in thousands of dollars)

CEO's other compensation

Value of the CEO's options when granted (in thousands of dollars)

Fraction of the CEO's compensation coming from stock options

Fractional ownership of the CEO in the firm (\% of outstanding shares)

Age of the CEO (years)

CEO tenure as CEO (years)

CEO tenure in the firm (years)

CEO as founder: 1 if the CEO is a member of the founding

family, 0 otherwise.

\section{BOARD Characteristics}

Board size (number of directors)

Number of inside directors

Number of outside directors

Number of gray directors

Number of directors who are CEOs of other firms

Number of board meetings during the fiscal year

Board reputation (number of outside directorships)

Number of reciprocal CEO interlocks

Number of reciprocal company interlocks

Director's retainer fee (in dollars)

\section{COMPANY Characteristics}

Firm size (natural log of assets)

Return on assets

Tobin's Q

Bank $(0,1)$ indicator
Mean

1013

297.82266

562.86676

0.21506

0.02110

57.71967

8.61639

24.61311

0.12951

13.05738

3.83115

7.97541

1.25082

2.16557

8.32007

10.58689

0.17213

0.34918

20726

8.53614

0.09769

1.09983

0.12951
Median

\section{1}

47

144.019

0.16140

1409

0.23402

$\begin{array}{cc}0.0014 & 0.06579 \\ 58 & 6.55018 \\ 6 & 7.99777 \\ 27 & 12.37261\end{array}$

\section{0}

0.33604

3.79417

2.09997

3.61047

1.45915

1.91797

3.26189

8.95949

0.46011

0.77589

9369

20000

1.17247

8.42668

0.088546

0.07866

0.98077

0.62408

0

0.33604 
Table 2

Incidence of Reciprocal CEO Interlocks

\begin{tabular}{ccc}
\hline CEO Interlock & Frequency & Percent \\
\hline 0 & 523 & \\
1 & 72 & 85.74 \\
2 & 12 & 11.80 \\
3 & 3 & 1.97 \\
& & 0.49 \\
\hline
\end{tabular}


Table 3

Means for the Sub-samples of Non CEO Interlocked and Reciprocal CEO Interlocked Firms

Standard deviations are reported in parentheses. The third column provides the absolute value of the difference between the two subsamples. Please refer to Table 1 for a full variable description.

Variables

\section{CEO Characteristics}

CEO's salary and bonus (in thousands of dollars)

CEO's other compensation

Value of the CEO's options when granted (in thousands of dollars)

Fraction of the CEO's compensation coming from stock options

Fractional ownership of the CEO in the firm (\% of outstanding shares)

Age of the CEO (years)

CEO tenure as CEO (years)

CEO tenure in the firm (years)

CEO as founder: 1 if the CEO is a member of the founding family, 0 otherwise.

\section{BOARD Characteristics}

Board size (number of directors)

Number of inside directors

Number of outside directors

Number of gray directors

Number of directors who are CEOs of other firms

Number of board meetings during the fiscal year

Board reputation (number of outside directorships)

Number of company interlocks

Director's retainer fee (in dollars)

\section{COMPANY Characteristics}

Firm size (natural log of assets)

Return on assets

Tobin's Q

Bank $(0,1)$ indicator

\section{Means of the Means of the Difference Sub-sample Sub-sample of Means N Without CEO with CEO Interlocks Interlocks \\ (Absolute)}

$\begin{array}{llll}608 & 977.49 & 1232.3 & 254.8^{\mathbf{a}}\end{array}$ (749.05) (604.32)

$\begin{array}{lll}609 & 285.6 & 372.13\end{array}$

(684.45) (694.17)

$\begin{array}{lll}607 & 550.78 & 636.36\end{array}$

(1478.9) (874.14)

$\begin{array}{lll}607 & 0.2087 & 0.2535\end{array}$

$(0.2365) \quad(0.2158)$

$610 \quad 0.0234$

(0.0696)

$610 \quad 57.539$

(6.7393)

6108.608

(8.1817)

$610 \quad 23.878$

(12.56)

$610 \quad 0.1434$

(0.3508)

0.0074

$(0.0325)$

58.805

$(5.1734)$

8.6667

(6.8296)

29.034

$(10.242)$

0.046

(0.2106)

$610 \quad 12.87$

(3.8728)

$610 \quad 3.8145$

(2.0609)

$610 \quad 7.7878$

(3.665)

$610 \quad 1.2677$

(1.4703)

$610 \quad 1.9943$

(1.88)

$603 \quad 8.3488$

(3.3505)

6109.0593

(8.0769)

$610 \quad 0.1358$

(0.4138)

$604 \quad 19733$

(9061.3)

14.184

(3.0672)

3.931

(2.3317)

9.1034

(3.0463)

1.1494

(1.3937)

3.1954

(1.829)

8.1494

(2.6873)

19.77

(8.5422)

1.6322

(1.1321)

26692

(9013.4)

$610 \quad 8.4418$

9.1034

(1.2504)

$608 \quad 0.0956$

(0.0787)

$610 \quad 1.0879$

(0.6106)

$610 \quad 0.1453$

(0.6106)
0.1076

(0.0783)

1.1716

(0.6992)

0.0345

(0.1835)
86.52

85.58

0.045

$0.016^{\mathrm{b}}$

$1.265^{\mathrm{c}}$

0.059

$5.157^{\mathrm{a}}$

$0.0974^{\mathrm{a}}$

$1.314^{\mathrm{a}}$

0.117

$1.316^{\mathrm{a}}$

0.1183

$1.201^{\mathrm{a}}$

0.1994

$10.71^{a}$

$1.496^{\mathrm{a}}$

$6958^{a}$

$0.662^{a}$

0.012

0.084

$0.1108^{\mathrm{a}}$

a: significant at the $1 \%$ level; b: significant at the 5\% level; c: significant at the $10 \%$ level. 
Table 4

Simple Probit and Step Probit Coefficient Estimates: Reciprocal CEO Interlocks

Coefficient estimates for simple probit and step probit models for reciprocal CEO interlocks. The dependent variable in the first column is a 0,1 indicator for the presence of at least one reciprocal CEO interlock. A reciprocal CEO interlock occurs when the CEO of firm $i$ serves as a director of firm $\mathrm{j}$ and the $\mathrm{CEO}$ of firm $\mathrm{j}$ serves as a director of firm $\mathrm{i}$. The dependent variable in the second column represents the actual number of reciprocal CEO interlocks. Both models include industry 0,1 dummy variables. Standard errors appear in parentheses below each estimate. Please refer to Table 1 for a full variable description.

\section{Variable}

Intercept

Natural log of the CEO's salary and bonus

Fraction of the CEO's total pay coming from stock options

Fractional ownership of the CEO in the firm (\% of outstanding shares)

CEO's age

Tenure of the $\mathrm{CEO}$ as $\mathrm{CEO}$

Tenure of the CEO with the firm

CEO as founder $(0,1)$

Natural logarithm of board size

Number of directors who are CEOs of other firms

Number of board meetings

Board reputation (total number of outside directorships)

Natural log of directors' fees

Firm size (natural logarithm of total assets)

Tobin's Q (market value of assets divided by the replacement value of assets)

Bank $(0,1)$ indicator

$\begin{array}{cc}\text { Simple Probit } & \text { Step Probit } \\ \text { Estimates } & \text { Estimates } \\ -7.21255^{\mathbf{b}} & -6.276977^{\mathbf{b}} \\ (3.15097) & (2.88393) \\ -0.27055 & -0.24324 \\ (0.17180) & (0.16202) \\ -0.78039^{\mathbf{b}} & -0.92461^{\mathbf{b}} \\ (0.42423) & (0.40328) \\ -1.20027 & -1.47192 \\ (1.15003) & (1.11179) \\ 0.02686 & 0.02246 \\ (0.01832) & (0.01724) \\ 0.0023589 & 0.0019446 \\ (0.01403) & (0.01315) \\ 0.01405^{\mathbf{c}} & 0.01349 \\ (0.00842) & (0.0079523) \\ -0.53074 & -0.44248 \\ (0.39509) & (0.36900) \\ -0.0062376 & 0.02491 \\ (0.42006) & (0.40057) \\ 0.07204 & 0.05174 \\ (0.04897) & (0.04647) \\ -0.07346^{\mathbf{b}} & -0.05449^{\mathbf{b}} \\ (0.03303) & (0.03094) \\ 0.05959^{\mathbf{a}} & 0.05335^{\mathbf{a}} \\ (0.01310) & (0.01215) \\ 0.48307 & 0.36416 \\ (0.30469) & (0.27827) \\ 0.10679 & 0.14642 \\ (0.11902) & (0.11329) \\ 0.32566^{\mathbf{c}} & 0.28013^{\mathbf{c}} \\ (0.17151) & (0.16035) \\ -0.53771 & -0.62684^{\mathbf{c}} \\ (0.36906) & (0.35986) \\ & \end{array}$

a: significant at the $1 \%$ level; b: significant at the 5\% level; c: significant at the $10 \%$ level. 
Table 5

Probit Coefficient Estimates: Reciprocal CEO Interlock

Coefficient estimates for probit models for CEO interlock. The dependent variable in both columns is a $(0,1)$ indicator for CEO interlock. Both estimations include industry $(0,1)$ dummies. Standard errors appear in parentheses below each estimate. Please refer to Table 1 and Section 5 for a full variable description.

\section{Variable}

Intercept

Natural log of the CEO's salary and bonus

Fraction of the CEO's total pay coming from stock options

Fractional ownership of directors and officers in the firm (\% of outstanding shares)

CEO's age

Tenure of the CEO as CEO

Tenure of the CEO with the firm

CEO as founder $(0,1)$

Natural logarithm of board size

Number of directors who are CEOs of other firms

Number of board meetings

Board reputation (total number of outside directorships)

Natural log of directors' fees

Firm size (natural logarithm of total assets)

Tobin's Q (market value of assets over replacement value of assets)

Bank $(0,1)$ indicator

Strategic objectives $(0,1)$ indicator

$\mathrm{CEO}$ in the nominating committee $(0,1)$ indicator
Expanded

Model

$-10.65051^{\mathrm{a}}$

(4.11945)

$-0.25043$

$(0.20387)$

$-1.00480^{b}$

$(0.40034)$

$-0.71865$

$(1.66181)$

0.02690

(0.02228)

0.0023589

$(0.01403)$

$0.01898^{\mathrm{c}}$

(0.01064)

$-0.29950$

(0.46969)

$-0.12137$

(0.57742)

0.05421

(0.06059)

$-0.08126^{\mathrm{b}}$

(0.04177)

$0.05796^{\mathrm{a}}$

(0.01559)

0.68913

(0.47844)

0.13175

(0.15807)

$0.33578^{\mathbf{b}}$

(0.17703)

$-1.40265^{\mathrm{c}}$

(0.78444)
Model

$-8.88757^{\mathbf{b}}$

(4.26295)

$-0.27456$

(0.21175)

$-0.86465^{\mathbf{b}}$

(0.41584)

$-0.90591$

(1.77586)

0.02425

(0.02296)

0.01761

$(0.01879)$

$0.02057^{\mathbf{c}}$

(0.01161)

$-0.27522$

(0.48404)

0.03875

(0.61053)

0.05125

$(0.06383)$

$-0.08123^{\mathbf{b}}$

(0.04044)

$0.06807^{\mathrm{a}}$

(0.01649)

0.66477

(0.48930)

0.14368

(0.16535)

$0.33565^{\mathrm{b}}$

(0.17711)

$-1.25772^{\mathrm{c}}$

(0.76420)

0.03486

(0.26820)

$2.25539^{\mathrm{a}}$

(0.69746)

a: significant at the $1 \%$ level; b: significant at the 5\% level; c: significant at the $10 \%$ level. 